\title{
Effect of dehydration temperature on physico-chemical properties and antioxidant capacity of goldenberry (Physalis peruviana L.)
}

\author{
Jéssica López ${ }^{1}$, Antonio Vega-Gálvez ${ }^{1}$, María José Torres ${ }^{1}$, Roberto Lemus-Mondaca ${ }^{1}$, \\ Issis Quispe-Fuentes ${ }^{1}$, and Karina Di Scala ${ }^{2 *}$
}

Health-conscious consumers prefer a nutritious diet with an increase in fruit intake because of their bioactive compounds. Dehydration is widely used to prolong fruit shelf life. This study researched the effect of convective dehydration on physicochemical properties, color, vitamin C, $\beta$-carotene, total phenolic content (TPC), flavonoids, and antioxidant capacity during dehydration of goldenberry (Physalis peruviana L.) fruits in the 50 to $90{ }^{\circ} \mathrm{C}$ temperature range. Chromatic parameters (L*, $\mathrm{a}^{*}$, and $\mathrm{b}^{*}$ ) as well as Chroma and hue angle were affected by drying temperature, which contributed to fruit discoloring during this process. Total phenolic content, flavonoids, and $\beta$-carotene increased from 321.05-356.68 mg gallic acid 100 $\mathrm{g}^{-1} \mathrm{DM}$, 99.25-144.29 mg quercetin equivalents $100 \mathrm{~g}^{-1} \mathrm{DM}$, and 722.30-783.16 mg $100 \mathrm{~g}^{-1}$ sample, respectively, at $90{ }^{\circ} \mathrm{C}$. Radical scavenging activity showed higher antioxidant activity at high temperatures than low temperatures. Both vitamin $\mathrm{C}$ content and TPC decreased as air-drying temperature decreased. A high correlation was observed between fruit TPC and flavonoids with antioxidant capacity. Based on these results, this fruit has potential for the development of new functional products.

Key words: Antioxidant characteristics, bioactive compounds, functional food.

\section{INTRODUCTION}

Today's consumers are very interested in the potential benefits of nutritional support for disease control or prevention through a healthy diet (Hassanien, 2011). There is a growing recognition of the potential role of functional foods to help reduce health risks and improve health. In particular, fruits contain many bioactive compounds associated with a strong antioxidant activity; this plays an important role in human nutrition because of free radical scavenging activities, donation of hydrogen atoms or electron, or chelate metal cations (Balasundram et al., 2006). Phenolic compounds have been associated with health benefits derived from high fruit and vegetable consumption (Balasundram et al., 2006).

Goldenberry or Cape-gooseberry (Physalis peruviana L.) is an upright herbaceous perennial semi-shrub found in subtropical zones. Its fruit is covered by a brilliant yellow peel and protected by an accrescent calyx that acts as a protective shield against insects, birds, diseases, and

${ }^{1}$ Universidad de La Serena, Departamento de Ingeniería de Alimentos, Av. Raúl Bitrán s/n 599, La Serena, Chile.

${ }^{2}$ Universidad Nacional de Mar del Plata, Facultad de Ingeniería, Juan B. Justo 4302. Mar del Plata 7600, Argentina.

*Corresponding author (kdiscala@fi.mdp.edu.ar).

Received: 11 March 2013.

Accepted: 31 May 2013.

doi: $10.4067 /$ S0718-58392013000300013 adverse climatic situations (Hassanien, 2011; Puente et al., 2011). The main benefits associated with goldenberries are its nutritional composition and bioactive components (Hassanien, 2011). In addition, they are an excellent source of provitamin $\mathrm{A}$, vitamin $\mathrm{C}, \mathrm{Fe}$, and some of the vitamin B-complex (Salazar et al., 2008).

Dehydration is one of the important unit operations used in formulating a functional food product. It is a post-harvest technology that aims to remove water up to the level at which microbial spoilage and deterioration reactions are minimized. Nowadays, dehydration is regarded not only as a preservation process, but also as a method for increasing value-added foods. It is well known that many quality changes occur during food drying (Di Scala and Crapiste, 2008; Vega-Gálvez et al., 2009). Thus, the current degree of acceptance of dehydrated foods in the market can be further expanded by improving product quality and process applications. Selecting appropriate control variables, such as air-drying temperature, can lead to higher yield from the point of view of operational and capital investment and produce a high-quality final product (Di Scala et al., 2011).

Several research studies have reported the influence of air-drying temperature on the relevant quality indices of several fruits, such as total phenolic content (Vega-Gálvez et al., 2009; Mrad et al., 2012), vitamin C (Di Scala and Crapiste, 2008; Vega-Gálvez et al., 2009; Di Scala et al., 2011; Mrad et al., 2012), color, $\beta$-carotene (Di Scala and 
Crapiste, 2008; Demiray et al., 2013), and antioxidant activity (Vega-Gálvez et al., 2009; López et al., 2010). However, little information is reported about the effects of drying conditions on the main quality characteristics of goldenberry.

The aim of this study was to evaluate the effect of air-drying temperature on drying kinetics, surface color, vitamin $\mathrm{C}, \beta$-carotene, total phenolic content, flavonoids, and antioxidant capacity of goldenberry during convective dehydration at 50,60, 70,80 and $90{ }^{\circ} \mathrm{C}$.

\section{MATERIALS AND METHODS}

\section{Raw materials and physico-chemical analysis}

Goldenberry samples were cultivated and purchased in Olmué (Agrícola Neuquén, Valparaíso Region), Chile. Samples were homogeneously selected based on harvest date, color, size, and freshness measured by visual analysis. They were refrigerated at $5{ }^{\circ} \mathrm{C}$ until the drying process. Moisture content was determined by AOAC method 934.06 (AOAC, 1990) with a vacuum drying oven (OVL570, Gallenkamp, Leicester, UK) and an analytical scale with an accuracy of $\pm 0.0001 \mathrm{~g}$ (CHYO, Jex120, Japan). Crude protein content was determined by the Kjeldahl method with a 6.25 conversion factor. Lipid content was determined by gravimetric analysis after Soxhlet extraction. Crude ash was estimated by incineration in a muffle furnace (Felisa, 360D) at 550 ${ }^{\circ} \mathrm{C}$. All methodologies followed the recommendations of the Official Methods of Analysis (AOAC, 1990). Acidity was determined by the adapted AOAC method 942.15A (AOAC, 1990), $\mathrm{pH}$ was measured with a potentiometer (Extech Instruments, Microcomputer pH-Vision 246072, USA), and total soluble sugar content was calculated with an Abbe refractometer (ATAGO, 1-T, Japan). All the analyses were triplicated and expressed in $\mathrm{g} 100 \mathrm{~g}^{-1}$ fruit.

\section{Drying experiments}

Drying experiments, performed in triplicate, were carried out at five temperatures $\left(50,60,70,80\right.$, and $\left.90^{\circ} \mathrm{C}\right)$ with a constant air flow of $1.5 \pm 0.2 \mathrm{~m} \mathrm{~s}^{-1}$ (perpendicular direction of sample). The goldenberry samples were arranged in a thin layer in a stainless steel basket with a $14.51 \pm 0.66$ $\mathrm{kg} \mathrm{m}^{-2}$ load density. The drying process was carried out in a convective dryer designed and built at the Department of Food Engineering of the Universidad de La Serena (Vega-Gálvez et al., 2009). Mass was measured on an analytical balance (SP402, Ohaus, New Jersey, USA) with an accuracy of $\pm 0.01 \mathrm{~g}$ at defined time intervals and connected to a PC by a system interface (RS232, Ohaus), which served as a monitor to record the data until constant weight (equilibrium condition) was reached.

\section{Quality parameters}

Surface color. The color of goldenberry was measured with a colorimeter (HunterLab, MiniScan ${ }^{\mathrm{TM}}$ XE Plus,
Reston, Virginia, USA). Color was expressed by CIE $L^{*}$ (whiteness or brightness), $a^{*}$ (redness/greenness), and $b^{*}$ (yellowness/blueness) coordinates, in addition to standard illuminant $\mathrm{D}_{65}$ and observer $10^{\circ}$ (Vega-Gálvez et al., 2009). Measurements were replicated five times and the results were averaged. Total color difference $(\Delta E)$ was calculated by Equation [1] where $L_{0}, a_{0}$, and $b_{0}$ are the control values for fresh fruits. Chroma (Equation [2]) and hue angle (Equation [3]) were also estimated.

$$
\begin{gathered}
\Delta E=\left[\left(a^{*}-a_{0}\right)^{2}+\left(b^{*}-b_{0}\right)^{2}+\left(L^{*}-L_{0}\right)^{2}\right]^{0.5} \\
\text { Chroma }=\left(a^{* 2}+b^{* 2}\right)^{0.5} \\
\text { Hue angle }=\tan ^{-1}\left(b^{*} / a^{*}\right)
\end{gathered}
$$

Vitamin C. Vitamin C extraction methods were carried out with extracting solutions of 5\% meta-phosphoric acid (MPA) according to the method by Milagres Campos et al. (2009) with some modifications.

Thirty milliliters of the extracting solutions were added to $5 \mathrm{~g}$ sample; the sample was then ground in a micro triturator for $5 \mathrm{~min}$ and filtered on a double layer of cheese cloth. Filtrates were centrifuged for $15 \mathrm{~min}$ at $5000 \mathrm{rpm}$ at $10{ }^{\circ} \mathrm{C}$. The supernatant was injected for chromatographic analysis.

\section{Chromatographic conditions}

The method applied is based on the study published by Esteve et al. (1997). The method consists of a Zorbax Eclipse XDB-C18, $4.6 \times 150 \mathrm{~mm}, 5$ um reversedphase column, a mobile phase containing $5 \mathrm{mM}$ cetyltrimethylammonium bromide as the ion-pairing agent, and $50 \mathrm{mM}$ potassium dihydrogen phosphate as buffer at $\mathrm{pH} 4.5$ (the solution was filtered through a $0.22 \mu \mathrm{m}$ filter for use in the chromatographer). All measurements were

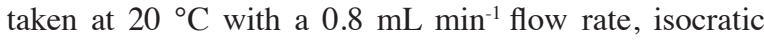
elution, and detection at $245 \mathrm{~nm}$. A high-performance liquid chromatography (HPLC) system (Agilent 1200, Santa Clara, California, USA) was employed for the analysis; the system was equipped with a high pressure pump, automatic injector with a $5 \mu \mathrm{L}$ loop, a UV-visible diode array detector controlled by ChemStation software (Agilent). Peak areas were used for the quantitative analysis. Calibration curves were prepared between 15 and $120 \mu \mathrm{g}$ of ascorbic acid (AA) $\mathrm{mL}^{-1}$ in $5 \%$ MPA. Total AA (vitamin $\mathrm{C}$ ) was estimated after reducing dehydroascorbic acid (DHA) with dithiothreitol. Results were expressed as mg AA retained in $100 \mathrm{~g}^{-1}$ dry weight. All measurements were triplicated.

\section{$\beta$-Carotene: Chromatographic conditions}

$\beta$-carotene extraction was performed according to the method by Koca et al. (2007) with hexane/acetone/ ethanol (50/25/25 v/v/v) solvent mixtures. Triplicate 1.0 $\mathrm{g}$ dehydrated goldenberry was extracted in $25 \mathrm{~mL}$ solvent with an orbital shaker (OS-20) for $30 \mathrm{~min}$ at $200 \mathrm{rpm}$. The extract was vacuum-filtered through a Buchner funnel with Whatman nr 1 . The residue was re-extracted until it 
became colorless. Filtrates were combined in a separatory funnel and washed with $15 \mathrm{~mL}$ distilled water; the upper layer was placed in a round-bottomed flask and the extract was evaporated to dryness. The extract was dissolved to a final $10 \mathrm{~mL}$ volume in ethyl acetate, the solution filtered through $0.45 \mu \mathrm{m}$ membrane filters, and $5 \mu \mathrm{L}$ injected for HPLC analysis.

The chromatographic conditions are based on the work of previous authors (Laur and Tian, 2011). Carotenoid analysis was performed with a HPLC system (Agilent 1200), which included a model G1311A quaternary pump, a model G1329B autosampler, a model G1316A column oven, and a model G1315D photodiode array detector. The column was an Agilent ZORBAX Eclipse XDB-C18, 4.6 $\mathrm{mm} \times 150 \mathrm{~mm}, 5 \mu \mathrm{m}$ connected to an Eclipse XDB-C18 guard column. The column temperature was controlled at $30{ }^{\circ} \mathrm{C}$ during the HPLC runs. Data were processed with the Agilent ChemStation software.

The flow rate was $1 \mathrm{~mL} \mathrm{~min}^{-1}$. Mobile phases were (A) acetonitrile: $\mathrm{H}_{2} \mathrm{O}$ :triethylamine (900:99:1, v/v/v) adjusted with $1 \mathrm{M}$ phosphoric acid $\mathrm{pH} 8.5$ and ethyl acetate (B). The gradient elution program was 0 to $5 \mathrm{~min}, 100$ to $75 \% \mathrm{~A} ; 5$ to $10 \mathrm{~min}, 75$ to $30 \% \mathrm{~A} ; 10$ to $13 \mathrm{~min}, 30$ to $0 \% \mathrm{~A} ; 13$ to $14 \mathrm{~min}, 0$ to $100 \% \mathrm{~A} ; 14$ to $15 \mathrm{~min}, 100 \% \mathrm{~A}$. Absorbance was read at $450 \mathrm{~nm}, \beta$-carotene was identified based on the retention time, and peak areas were compared with authentic standards. Calibration curves were prepared between 30 and $400 \mu \mathrm{g} \beta$-carotene $\mathrm{mL}^{-1}$. Results were expressed as $\beta$-carotene $100 \mathrm{~g}^{-1}$ sample.

\section{Total phenolic content}

Total phenolic content (TPC) was determined by the colorimetric method with Folin-Ciocalteu reagent (FC) according to Chuah et al. (2008) with modifications. A 0.5 $\mathrm{mL}$ aliquot of fruit extract solution was transferred to a glass tube to which $0.5 \mathrm{~mL}$ of reactive $\mathrm{FC}$ was added after 5 min, and $2 \mathrm{~mL} \mathrm{Na}_{2} \mathrm{CO}_{3}$ solution $\left(200 \mathrm{mg} \mathrm{mL}^{-1}\right)$ added and shaken. The sample was then mixed in a vortex mixer and the reaction continued for $15 \mathrm{~min}$ at room temperature. Afterward, $10 \mathrm{~mL}$ of ultrapure water was added and the formed precipitate removed by centrifugation (5804 R, Eppendorf, Hamburg, Germany) for $5 \mathrm{~min}$ at $4000 \mathrm{rpm}$. Finally, absorbance was measured with a spectrophotometer (Spectronic $\AA$ 20, GenesysTM131, Illinois, USA) at $725 \mathrm{~nm}$ and compared to a gallic acid (GA) calibration curve. Results were expressed as mg GA $100 \mathrm{~g}^{-1}$ DM. All reagents were purchased from Merck (Merck KGaA, Darmstadt, Germany). All measurements were triplicated.

\section{Flavonoid content}

Total flavonoids were measured by a colorimetric assay. A $0.5 \mathrm{~mL}$ aliquot of goldenberry extract solution was added to a $5 \mathrm{~mL}$ volumetric flask containing $2 \mathrm{~mL}$ distilled water. At time zero, $0.15 \mathrm{~mL} \mathrm{NaNO}_{2}$ aqueous solution (5 g 100 $\left.\mathrm{mL}^{-1}\right)$ was added to the flask. After $5 \mathrm{~min}, 0.15 \mathrm{~mL} \mathrm{AlCl}_{3}$ aqueous solution (10 g $100 \mathrm{~mL}^{-1}$ ) was added. At $6 \mathrm{~min}, 1$ $\mathrm{mL} 1 \mathrm{M} \mathrm{NaOH}$ was added to the mixture. The reaction flask was immediately diluted to volume by adding 1.2 $\mathrm{mL}$ distilled water and thoroughly mixed. Absorbance of the mixture was determined at $415 \mathrm{~nm}$ as compared to the prepared water blank. Total extract flavonoids were expressed as mg quercetin equivalents $100 \mathrm{~g}^{-1}$ dry weight.

\section{Antioxidant activity}

Extraction. Extraction was performed according to a method by Vasco et al. (2008), which was modified. Two grams of dried goldenberry or $6 \mathrm{~g}$ of fresh goldenberry were extracted twice at room temperature under continuous stirring (orbital shaker, OS-20, Boeco, Hamburg, Germany) for $1 \mathrm{~h}$ with $20 \mathrm{~mL}$ methanol:water $(50: 50 \mathrm{v} / \mathrm{v})$ mixture and then with $20 \mathrm{~mL}$ acetone:water $(70: 30 \mathrm{v} / \mathrm{v})$ with intermittent centrifugation $(4000 \mathrm{rpm}$, $\left.15 \mathrm{~min}, 5^{\circ} \mathrm{C}\right)$. A total of three extractions were performed with acetone:water $(70: 30 \mathrm{v} / \mathrm{v})$. Four supernatants were collected and then concentrated to dryness with a rotary evaporator at $40{ }^{\circ} \mathrm{C}$. The mixture was then worked up as described above and analyzed to quantify antioxidant activity.

DPPH scavenging activity assay. Free radical scavenging activity of the samples was determined by the 2,2-diphenyl-1-picrylhydrazyl (DPPH) method (Turkmen et al., 2005) with some modifications. Different extract dilutions were triplicated. An aliquot of $2 \mathrm{~mL}$ of $0.15 \mathrm{mM}$ DPPH radical in methanol was added to a test tube with 1 mL of the sample extract. The reaction mixture was mixed in a vortex for $30 \mathrm{~s}$ and left to stand at room temperature in the dark for $20 \mathrm{~min}$. Absorbance was measured at 517 nm with a spectrophotometer (Spectronic 20 GenesysTM, Illinois, USA). The spectrophotometer was calibrated with $80 \% \quad(\mathrm{v} / \mathrm{v})$ methanol. Calibration curves were prepared for each assay with Trolox (6-hydroxy-2,5,7,8tetramethylchroman-2-carboxylic acid) and results expressed as millimoles of Trolox equivalents (TE) per $100 \mathrm{~g}$ dry weight $\left(\mathrm{mM} \mathrm{TE} 100 \mathrm{~g}^{-1}\right)$.

Ferric reducing antioxidant power (FRAP). The antioxidant activity of goldenberry extracts was determined by a modified method of the ferric reducing antioxidant power (FRAP) assay according to Benzie and Strain (1999). The FRAP reagent was prepared as a mixture of $0.1 \mathrm{~mol} \mathrm{~L}^{-1}$ acetate buffer ( $\left.\mathrm{pH} 3.6\right), 10 \mathrm{mmol} \mathrm{L}^{-1}$ 2,4,6-tris(2-pyridyl)-s-triazine (TPTZ), and $20 \mathrm{mmol} \mathrm{L}^{-1}$ ferric chloride (10:1:1 v:v:v). To the $0.06 \mathrm{~mL}$ sample, 1.8 $\mathrm{mL}$ reagent and $0.18 \mathrm{~mL}$ water were added. The reaction mixture was incubated at $37^{\circ} \mathrm{C}$ for $120 \mathrm{~min}$. An increase in absorbance was monitored at $593 \mathrm{~nm}$ as compared to a blank. The FRAP reagent was prepared fresh on each measuring day and the blank consisted of $1.8 \mathrm{~mL}$ reagent, $0.18 \mathrm{~mL}$ water, and $0.06 \mathrm{~mL}$ methanol $(80 \% \mathrm{v} / \mathrm{v})$. Final absorbance of each sample was compared with data 
obtained from the standard curve prepared from Trolox; results were expressed as millimoles of Trolox equivalents (TE) per $100 \mathrm{~g}$ dry weight (mM TE $\left.100 \mathrm{~g}^{-1}\right)$.

\section{Statistical analysis}

The effect of air-drying temperature on each quality parameter was estimated with Statgraphics Plus 5 (Statistical Graphics Corp., Herndon, Virginia, USA). Results were analyzed by ANOVA. Differences among means were analyzed by the least significant difference (LSD) test with a $\alpha=0.05$ significance level and a $95 \%$ confidence interval $(\mathrm{P}<0.05)$. In addition, the multiple range test (MRT) included in the statistical program was used to demonstrate the existence of homogeneous groups within each parameter. Pearson's linear correlation coefficient was also determined between the antioxidant capacity and antioxidant substances.

\section{RESULTS AND DISCUSSION}

\section{Proximate analysis and drying kinetics}

Proximate analysis of fresh goldenberry is shown in Table 1. Reported values were close to those informed by Puente et al. (2011) and Hassanien (2011).

The experimental drying curves of a material usually relate the moisture ratio (MR) of the material to be dried as a function of time for a determined process temperature. Experimental drying curves for the five applied temperatures $\left(50,60,70,80\right.$, and $90{ }^{\circ} \mathrm{C}$ ) are shown in Figure 1. Drying rates increased with air-drying temperature with a clear exponential trend; a typical case is where moisture from the solid material evaporates first from the moisture layer on the surface and continuously decreases until water moves from the inside of the solid material by diffusion processes (Di Scala and Crapiste, 2008).

Drying time to reach a similar moisture content decreased as the temperature process increased. For example, the time required to achieve a moisture ratio of 0.1 at $90{ }^{\circ} \mathrm{C}$ is $180 \mathrm{~min}$ compared with almost $800 \mathrm{~min}$ to reach that moisture content at $50{ }^{\circ} \mathrm{C}$. These results are comparable to those reported in previous studies for drying fruits such as sour cherries, strawberries, blueberries, sweet cherries, and sweet pepino (Doymaz, 2008; Di Scala et al., 2011; Uribe et al., 2011).

Table 1. Chemical characterization of goldenberry fruit.

\begin{tabular}{|c|c|}
\hline Parameter & g $100 \mathrm{~g}^{-1}$ fresh sample \\
\hline Moisture & $83.45 \pm 0.15$ \\
\hline Protein & $1.23 \pm 0.15$ \\
\hline Fat & $0.35 \pm 0.05$ \\
\hline Crude fiber & $2.41 \pm 0.17$ \\
\hline Ash & $0.77 \pm 0.03$ \\
\hline Available carbohydrates ${ }^{1}$ & $11.79 \pm 0.10$ \\
\hline Acidity, $\%$ citric acid & $2.01 \pm 0.09$ \\
\hline $\mathrm{pH}^{2}$ & $3.51 \pm 0.10$ \\
\hline Soluble content, ${ }^{\circ}$ Brix & $13.96 \pm 0.16$ \\
\hline
\end{tabular}

${ }^{1}$ By difference. ${ }^{2}$ Dimensionless.

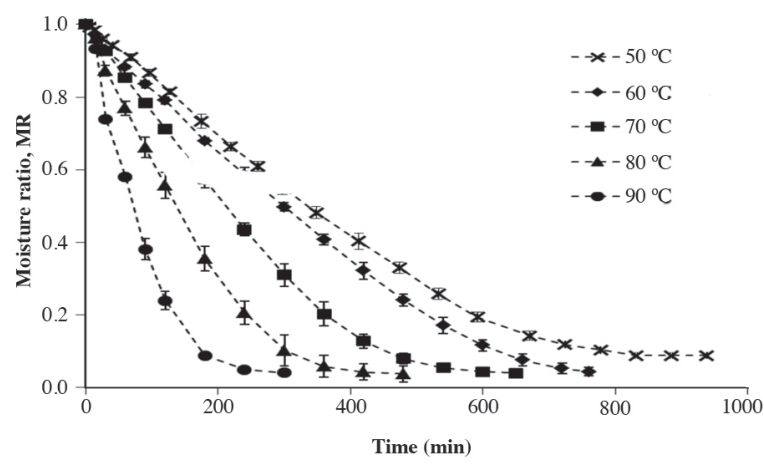

Figure 1. Experimental drying curves for goldenberry samples at different air-drying temperatures. Results are mean \pm standard deviation, $n=3$.

Therefore, sensitive material (as in the case of goldenberry) can be dried at higher temperatures in thinbed layers because of the shorter drying period. Carefully selecting air-drying temperature does not only take into account the minimization of process time but also the maintenance or enhancement final fruit quality. These aspects will be analyzed below.

\section{Surface color}

The color of the food surface is the first quality parameter evaluated by consumers and is critical in product acceptance, even before it is tasted. The chromatic parameters $\mathrm{L}^{*}$ (whiteness or brightness/darkness), $\mathrm{a}^{*}$ (greenness-redness), and $\mathrm{b}^{*}$ (blueness-yellowness) have been widely used to describe color changes during thermal processing of agricultural products; they have been related to the types and quantities of some components present in those products (Bahloul et al., 2009). Mean color values of fresh and dried goldenberry chromatic parameters are shown in Table 2. Values of fresh goldenberry $\mathrm{a}^{*}, \mathrm{~b}^{*}$, and $\mathrm{L}^{*}$ were $20.186,53.75$, and 51.978, respectively. Except for $\mathrm{a}^{*}$, the $\mathrm{b}^{*}$ and $\mathrm{L}^{*}$ coordinates exhibited significant differences between fresh and dehydrated samples $(\mathrm{P}<0.05)$. All treatments decreased brightness $\left(\mathrm{L}^{*}\right)$, which indicates that fresh fruits had a bright color as well as high luminosity as compared with processed samples. There were reports showing that the higher the degree of browning, the lower the sample $L^{*}$ value (Prathapan et al., 2009). Moreover, dehydrated physalis fruits become darker probably because of an extensive Maillard reaction (Vega-Gálvez et al., 2009). These chemical reactions are a consequence of reducing sugars and amino acids in the material being dehydrated (Perera, 2005). The goldenberry fruit has different amino acids because of its protein content. Sugars, such as fruit glucose content, are very similar to other Solanaceae fruits and are approximately $0.5 \%$ (Puente et al., 2011). Some non-enzymatic causes of browning in foods include the Maillard reaction, auto-oxidation reactions involving phenolic compounds, and the formation of iron-phenol 
Table 2. Effect of air-drying temperature on chromatic coordinates ( $L^{*}, a^{*}$, and $\left.b^{*}\right)$, surface color, Chroma, and hue angle of fresh and dehydrated goldenberries samples.

\begin{tabular}{|c|c|c|c|c|c|c|}
\hline & \multicolumn{6}{|c|}{ Temperature $\left({ }^{\circ} \mathrm{C}\right)$} \\
\hline & Fresh & 50 & 60 & 70 & 80 & 90 \\
\hline $\mathrm{L}^{*}$ & $51.978 \pm 0.683 a$ & $41.048 \pm 1.461 b$ & $40.316 \pm 1.027 b$ & $41.832 \pm 2.249 b$ & $38.572 \pm 1.032 \mathrm{c}$ & $32.498 \pm 1.558 \mathrm{~d}$ \\
\hline$a^{*}$ & $20.186 \pm 6.450 \mathrm{a}$ & $20.962 \pm 0.462 \mathrm{a}$ & $20.314 \pm 0.766 a$ & $20.81 \pm 0.391 \mathrm{a}$ & $20.036 \pm 1.293 \mathrm{a}$ & $17.472 \pm 1.291 \mathrm{a}$ \\
\hline$b^{*}$ & $53.755 \pm 0.965 a$ & $42.190 \pm 2.598 b$ & $40.038 \pm 1.018 b, c$ & $45.76 \pm 2.553 \mathrm{~d}$ & $38.062 \pm 3.926 \mathrm{c}$ & $30.452 \pm 3.072 \mathrm{e}$ \\
\hline$\Delta \mathrm{E}$ & & $15.993 \pm 2.790 \mathrm{a}, \mathrm{b}$ & $18.142 \pm 0.927 b, c$ & $13.023 \pm 3.267 \mathrm{a}$ & $20.833 \pm 3.731 \mathrm{c}$ & $30.761 \pm 3.408 \mathrm{~d}$ \\
\hline Hue angle & $1.215 \pm 0.113 \mathrm{a}$ & $1.109 \pm 0.031 b$ & $1.101 \pm 0.013 b, c$ & $1.143 \pm 0.016 \mathrm{~d}$ & $1.085 \pm 0.019 \mathrm{c}$ & $1.049 \pm 0.018 \mathrm{e}$ \\
\hline Chroma & $57.728 \pm 1.764 a$ & $47.129 \pm 2.194 b$ & $44.900 \pm 1.129 b, c$ & $50.275 \pm 2.445 \mathrm{~d}$ & $43.020 \pm 4.051 \mathrm{c}$ & $35.113 \pm 3.272 \mathrm{e}$ \\
\hline
\end{tabular}

Results are mean \pm standard deviation, $\mathrm{n}=3$. Different letters in the same row indicate that values are significantly different $(\mathrm{P}<0.05)$.

complexes (López-Nicolás and García-Carmona, 2010). At $90{ }^{\circ} \mathrm{C}$, parameter $\mathrm{b}^{*}$ showed a decrease to $43 \%$ in its value as compared with fresh samples; this generates brown products caused by non-enzymatic reactions (Vega-Gálvez et al., 2009).

The effects of air-drying temperature on total color difference $(\Delta \mathrm{E})$ of goldenberry are also shown in Table 2 . The highest $\Delta \mathrm{E}$ value was observed at $90{ }^{\circ} \mathrm{C}$ as compared with the rest of the treatments $(\mathrm{P}<0.05)$ because of the effect of high temperature on heat-sensitive components, such as proteins and carbohydrates; this indicates appreciable differences in dehydrated goldenberry color according to Chen (2008). Goldenberry color changes caused by the thermal treatment may be caused not only by the non-enzymatic browning reaction, but also by the destruction of pigments present in the fruits, such as $\beta$-carotene.

The saturation index or Chroma $\left(\mathrm{C}^{*}\right)$ is a measure of intensity or saturation of color, which varies from dull (low value) to vivid (high value). The results of variation of this $C^{*}$ parameter, as well as the hue angle, are also reported in Table 2. It can be observed that both indices are affected by air-drying temperature $(\mathrm{P}<0.05)$. Dehydrated samples were significantly different to fresh samples. At $90{ }^{\circ} \mathrm{C}$, both color indices showed the lowest values, which indicates discoloration of the original fruit color (VegaGálvez et al., 2009).

\section{Vitamin C}

Vitamin $\mathrm{C}$ is considered as an indicator of food processing quality because of its low stability during thermal treatments (Podsędek, 2007). Vitamin C content of fresh and dehydrated physalis fruits for the five applied temperatures are shown in Figure 2. It can be observed that drying temperature greatly influenced this component as compared with the corresponding value of the fresh samples $(\mathrm{P}<0.05)$. There was a clear tendency between temperature and vitamin $\mathrm{C}$ loss. In fact, an increase in drying temperature notably reduced the initial vitamin content (e.g., the content was not detectable at $90^{\circ} \mathrm{C}$ ). This could be explained by irreversible oxidative processes during drying or rehydration and water lixiviation of this water-soluble vitamin (Perera, 2005; Vega-Gálvez et al., 2009). Comparable results were reported by other authors when working with red pepper (Vega-Gálvez et al., 2009),

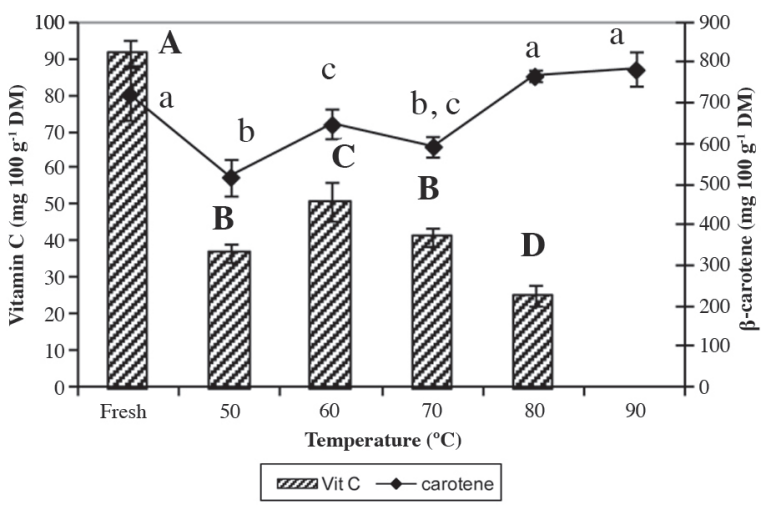

Figure 2. Effect of air-drying temperature on vitamin $C$ and $\beta$-carotene of fresh and dehydrated goldenberry samples. Identical letters above bars indicate no significant difference $(P<0.05)$.

blueberries (López et al., 2010), and sweet pepino (Di Scala et al., 2011).

\section{$\beta$-Carotene}

Effects of air-drying temperature on fruit pigments ( $\beta$-carotene) are also shown in Figure 2. The initial content (722 mg $100 \mathrm{~g}^{-1} \mathrm{DM}$ ) was higher than values reported for fresh tomatoes, marigold flowers, grapes, mangoes, and apples (Lavelli et al., 2007; Charoensiri et al., 2009). Besides its provitamin A activity, other physiological functions such as cell-to-cell communication, immunomodulatory effect, and UV skin protection have been documented (Lavelli et al., 2007). $\beta$-Carotene, which is a carotenoid, is a fat-soluble pigment that avoids the breakdown of chromoplasts by heat treatment or mechanical damage and improves their extraction with organic solvents and bioavailability, but not their loss by lixiviation (van het Hof et al., 2000). The degradation of $\beta$-carotene was more evident at $50{ }^{\circ} \mathrm{C}(28 \%$ loss of its original value). Some authors concluded that the loss of this compound at low temperatures was highly influenced by the length of drying (Demiray et al., 2013). However, drying at 80 and $90{ }^{\circ} \mathrm{C}$ did not show any significant differences when compared with fresh samples $(\mathrm{P}<0.05)$.

\section{Total phenolic content and flavonoids}

Phenolic compounds structurally involve an aromatic ring that bears one or more hydroxyl substituents; they range 
from simple phenolic molecules to highly polymerized compounds. Despite this structural diversity, the group of compounds is often referred to as polyphenols (Balasundram et al., 2006). Initial TPC value for fresh goldenberries is in the range of values reported for other fruits such as plums, blackberries, cranberries, and strawberries informed in previous studies (Balasundram et al., 2006; Vasco et al., 2008). Furthermore, initial fruit TPC belonged to the intermediate TPC group according to Vasco et al. (2008). In addition, TPC observed in this study was higher than TPCs reported in previous research studies (Vasco et al., 2008; Rockenbach et al., 2008). Different authors indicate wide variations between the total phenolic content of different fruits or even for the same fruit. These differences may be due to the complexity of these groups of compounds as well as the methods of extraction and analysis (Balasundram et al., 2006).

It can be observed in Table 2 that air-drying temperature decreased initial goldenberry TPC; however, except at 90 ${ }^{\circ} \mathrm{C}$, the results reported for dehydrated samples did not show any significant differences in the 50 to $80{ }^{\circ} \mathrm{C}$ range $(\mathrm{P}<0.05)$. According to Mrad et al. (2012), a decrease in TPC during drying can also be attributed to the binding of polyphenols with other compounds (proteins) or to alterations in the chemical structure of polyphenols which cannot be extracted or determined by available methods.

The formation of phenolic compounds at high temperatures (i.e., $90{ }^{\circ} \mathrm{C}$ ) might be caused by the availability of phenolic precursor molecules through nonenzymatic interconversion between phenolic molecules (Vega-Gálvez et al., 2009).

Flavonoids constitute the largest group of plant phenols and account for over half of the 8000 naturally occurring phenolic compounds (Balasundram et al., 2006). The potential benefits of flavonoids for human health, as well as other phenolic compounds, are supported by epidemiological and in vitro evidence of antioxidant, cardioprotective, and anticarcinogenic activities; they also protect against other non-transmissible chronic diseases (Celli et al., 2011). It can be observed in Table 2 that air-drying temperature decreased initial goldenberry flavonoid content, with the exception at $90{ }^{\circ} \mathrm{C}(\mathrm{P}<0.05)$. Results did not present any significant differences in the 50 to $80{ }^{\circ} \mathrm{C}$ range for TPC. Similar results were reported by Bonghi et al. (2012). Besides this antioxidant property, some flavonoids, such as myricetin and quercetin, have shown the interesting ability to inhibit ascorbate oxidase and prevent enzymatic oxidation of ascorbic acid (Marín et al., 2002).

The health properties of phenolic compounds have been extensively studied from the epidemiological point of view by directly searching for their effect on enzymatic systems and/or their effect on physiological functions. Based on the approach of assigning a health property to these compounds, food functionality is going to depend on their content, intake, and bioavailability (Marín et al., 2002). Bioavailability of these compounds can also be affected by differences in cell wall structures, location of glycosides in cells, and binding of phenolic compounds within the food matrix, which are directly related to fruit drying conditions (Balasundram et al., 2006).

\section{Antioxidant capacity}

Research on radical scavenging activity was based on air-drying temperature $(\mathrm{P}<0.05)$ as seen in Table 3. Antioxidant capacity associated with phenolic compounds was determined by FRAP assay and DPPH methodologies. The different drawbacks and advantages of each one of the available antioxidant capacity assays make it necessary to use different techniques (Rufino et al., 2011). Fresh goldenberry exhibited values of 53.97 $\pm 1.23 \mathrm{Mm}$ TE $100 \mathrm{~g}^{-1}$ dry weight and $99.70 \pm 3.1 \mathrm{Mm}$ TE $100 \mathrm{~g}^{-1}$ DM for DPPH and FRAP, respectively. When comparing dehydrated samples, maximum antioxidant capacity was observed at $90{ }^{\circ} \mathrm{C}$ for both FRAP and DPPH methodologies, which coincides with the higher TPC and flavonoid content. The generation and accumulation of compounds with a varying degree of antioxidant activity during food dehydration could also develop antagonistic or synergistic effects between themselves or with the other sample constituents. These complex chemical interactions that influence functional properties of food during drying are still being researched (Di Scala et al., 2011). In addition, the lowest value was observed at 50 ${ }^{\circ} \mathrm{C}$ because of possible longer drying times (Demiray et al., 2013).

Antioxidant capacity may be related to the amount of vitamin $\mathrm{C}$ and -carotene, TPC, and flavonoids since

Table 3. Effect of air-drying temperature on TPC, flavonoids, free radical scavenging activity (DPPH), and ferric reducing antioxidant power (FRAP) of fresh and dehydrated goldenberry samples.

\begin{tabular}{|c|c|c|c|c|c|c|}
\hline Analysis & Fresh & $50^{\circ} \mathrm{C}$ & $60^{\circ} \mathrm{C}$ & $70^{\circ} \mathrm{C}$ & $80^{\circ} \mathrm{C}$ & $90^{\circ} \mathrm{C}$ \\
\hline $\mathrm{TPC}^{1}$ & $321.05 \pm 31.45 \mathrm{a}$ & $239.07 \pm 45.26 b$ & $200.68 \pm 6.80 b$ & $230.12 \pm 20.19 b$ & $232.67 \pm 26.49 b$ & $356.68 \pm 22.23 a$ \\
\hline Flavonoids $^{2}$ & $99.25 \pm 24.32 \mathrm{a}$ & $71.41 \pm 3.84 b$ & $73.05 \pm 7.62 b$ & $80.60 \pm 4.37 b$ & $74.43 \pm 19.34 b$ & $144.29 \pm 11.14 \mathrm{c}$ \\
\hline FRAP $^{3}$ & $99.70 \pm 3.10 \mathrm{a}$ & $54.48 \pm 6.92 b$ & $64.17 \pm 8.47 b$ & $55.65 \pm 9.00 \mathrm{~b}$ & $69.78 \pm 23.80 b$ & $109.81 \pm 12.70 \mathrm{a}$ \\
\hline $\mathrm{DPPH}^{4}$ & $53.97 \pm 1.23 \mathrm{a}$ & $29.59 \pm 0.64 b$ & $31.30 \pm 1.25 b, c$ & $32.16 \pm 3.03 \mathrm{~b}, \mathrm{c}$ & $30.971 \pm 2.74 b, c$ & $35.32 \pm 5.26 c$ \\
\hline
\end{tabular}

Results are mean \pm standard deviation, $\mathrm{n}=3$. Different letters in the same row indicate that values are significantly different $(\mathrm{P}<0.05)$.

${ }^{1}$ Total phenolic content: Gallic acid (GA) equivalents $100 \mathrm{~g}^{-1}$ dry weight.

${ }^{2} \mathrm{mg}$ quercetin equivalents $100 \mathrm{~g}^{-1}$ dry weight.

${ }^{3}$ Ferric reducing antioxidant power: $\mathrm{mM}$ TE $100 \mathrm{~g}^{-1}$ dry weight.

${ }^{4}$ 2,2-Diphenyl-12-picryl-hydrazyl method: $\mathrm{mM}$ TE $100 \mathrm{~g}^{-1}$ dry weight; $\mathrm{TE}=$ Trolox equivalent. 
these compounds act as scavengers of the free radicals produced during oxidation reactions. In order to explore the influence of the phytochemical constituents on goldenberry antioxidant capacity, Pearson's linear correlation coefficient was determined between the antioxidant capacity and the main antioxidant substances (vitamin C, $\beta$-carotene, TPC, and flavonoids). With regard to DPPH, Pearson's coefficients were TPC (0.6062), flavonoids (0.3404), vitamin C (0.7125), and $\beta$-carotene (0.3641). When analyzing FRAP, results were TPC (0.9287), flavonoids (0.8869), vitamin C $(-0.0320)$, and $\beta$-carotene $(0.780)$. Therefore, the higher correlation for DPPH was observed for vitamin $\mathrm{C}\left(\mathrm{r}^{2}=\right.$ $0.5076)$; the observed trend for FRAP was TPC $\left(r^{2}=\right.$ $0.8624)$, flavonoids $\left(r^{2}=0.7865\right)$, and $\beta$-carotene $\left(r^{2}=\right.$ $0.6085)$. The evaluation of different reaction kinetics of goldenberry extracts depend on the nature of the antioxidants being tested. $\beta$-Carotene and phenolic compounds, which are major contributors to goldenberry antioxidant activity, have different behavior patterns in response to drying temperature, oxygen, and other processing factors (Stojanovic and Silva, 2007). Based on our results, a high correlation was observed between fruit TPC and flavonoids with antioxidant capacity. Thus, goldenberry could be considered as an important source of biologically active components with high antioxidant activity (Julián-Loaeza et al., 2011).

\section{CONCLUSIONS}

The results found in this study are essential in order to obtain the optimum benefits of bioactive compounds present in goldenberry fruits during drying. Given its vitamin $\mathrm{C}$ and $\beta$-carotene content, total phenolic content, and flavonoids, this fruit is considered to be a potential functional dried product. Controlled air-drying temperatures can lead to high quality food characteristics from a sensorial (color) and nutritional point of view (vitamin $\mathrm{C}$ and antioxidant capacity). Based on our results, a high correlation was observed between total phenolic content and flavonoids with goldenberry antioxidant capacity determined by ferric reducing antioxidant power (FRAP) analysis. Thus, this fruit could be considered as an important source of biologically active components with high antioxidant activity to assess the requirements of today's consumers, who are very interested in the potential role of functional foods.

\section{ACKNOWLEDGEMENTS}

The authors gratefully acknowledge the Research Department of the Universidad de La Serena (DIULS), Chile for its financial support and the Consejo Nacional de Investigaciones Científicas y Técnicas (CONICET) of Argentina.

\section{LITERATURE CITED}

AOAC. 1990. Official method of analysis. $15^{\text {th }}$ ed. Association of Official Analytical Chemists (AOAC), Washington D.C., USA.

Bahloul, N., N. Boudhrioua, M. Kouhila, and N. Kechaou. 2009. Effect of convective solar drying on colour, total phenols and radical scavenging activity of olive leaves (Olea europaea L.) International Journal of Food Science and Technology 44:25612567.

Balasundram, N., K. Sundram, and S. Samman. 2006. Phenolic compounds in plants and agri-industrial by-products: Antioxidant activity, occurrence, and potential uses. Food Chemistry 99:191203.

Benzie, I.F.F., and J.J. Strain. 1999. Ferric reducing/antioxidant power assay: Direct measure of total antioxidant activity of biological fluids and modified version for simultaneous measurement of total antioxidant power and ascorbic acid concentration. Methods in Enzymology 299:15-27.

Bonghi, C., F.M. Rizzini, A. Gambuti, L. Moio, L. Chkaiban, and P. Tonutt. 2012. Phenol compound metabolism and gene expression in the skin of wine grape (Vitis vinifera L.) berries subjected to partial postharvest dehydration. Postharvest Biology and Technology 67:102-109.

Celli, G., A. Pereira-Netto, and T. Beta. 2011. Comparative analysis of total phenolic content, antioxidant activity, and flavonoids profile of fruits from two varieties of Brazilian cherry (Eugenia uniflora L.) throughout the fruit developmental stages. Food Research International 44:2442-2451.

Charoensiri, R., R. Kongkachuichai, P. Suknicom, and S. Sungpuag. 2009. Beta-carotene, lycopene, and alpha-tocopherol contents of selected Thai fruits. Food Chemistry 113:202-207.

Chen, X.D. 2008. Food drying fundamentals. p. 1-54. In X.D. Chen, and A.S. Mujumdar (eds.) Drying technologies in food processing. Wiley-Blackwell Publishing, West Sussex, UK.

Chuah, A.M., Y-C. Lee, T. Yamaguchi, H. Takamura, L-J. Yin, and T. Matoba. 2008. Effect of cooking on the antioxidant properties of coloured peppers. Food Chemistry 111:20-28.

Demiray, E., Y. Tulek, and Y. Yilmaz. 2013. Degradation kinetics of lycopene, $\beta$-carotene and ascorbic acid in tomatoes during hot air drying. LWT-Food Science and Technology 50:172-176.

Di Scala, K., and G. Crapiste. 2008. Drying kinetics and quality changes during drying of red pepper. LWT-Food Science and Technology 41:789-795.

Di Scala, K., A. Vega-Gálvez, E. Uribe, R. Oyanadel, M. Miranda, J. Vergara, et al. 2011. Changes of quality characteristics of pepino fruit (Solanum muricatum Ait) during convective drying. International Journal of Food Science and Technology 46:746753.

Doymaz, I. 2008. Convective drying kinetics of strawberry. Chemical Engineering and Processing: Process Intensification 47:914-919.

Esteve, M.J., R. Farré, A. Frigola, and J.M. Garcia-Cantabella. 1997. Determination of ascorbic and dehydroascorbic acids in blood plasma and serum by liquid chromatography. Journal of Chromatography B 688:345-349.

Hassanien, M.F.R. 2011. Physalis peruviana: A rich source of bioactive phytochemicals for functional foods and pharmaceutical. Food Reviews International 27(3):259-273.

Julián-Loaeza, A.P., N.F. Santos-Sánchez, R. Valadez-Blanco, B.S. Sánchez-Guzmán, and R. Salas-Coronado. 2011. Chemical composition, color, and antioxidant activity of three varieties of Annona diversifolia Safford fruits. Industrial Crops and Products 34:1262-1268.

Koca, N., H.S. Burdurlu, and F. Karadeniz. 2007. Kinetics of colour changes in dehydrated carrots. Journal of Food Engineering 78:449-455.

Laur, L.M., and L. Tian. 2011. Provitamin A and vitamin C contents in selected California-grown cantaloupe and honeydew melons and imported melons. Journal of Food Composition and Analysis 24:194-201. 
Lavelli, V., B. Zanoni, and A. Zaniboni. 2007. Effect of water activity on carotenoid degradation in dehydrated carrots. Food Chemistry 104:1705-1711.

López, J., E. Uribe, A. Vega-Gálvez, M. Miranda, J. Vergara, E. Gonzalez, and K. Di Scala. 2010. Effect of air temperature on drying kinetics, vitamin $\mathrm{C}$, antioxidant activity, total phenolic content, non-enzymatic browning and firmness of blueberries variety O’Neil. Food and Bioprocess Technology 3:772-777.

López-Nicolás, M.J. and F. García-Carmona. 2010. Enzymatic and nonenzymatic degradation of polyphenols. p. 101-103. In de la Rosa, L., E. Alvarez-Parrilla and G. Gónzalez-Aguilar (eds.) Fruit and vegetables phytochemicals. Wiley-Blackwell Publishing, Ames, Iowa, USA.

Marín, F.R., M.J. Frutos, M.J. Pérez-Alvarez, F. Martinez-Sánchez, and J.A. del Río. 2002. Flavonoids as nutraceuticals: Structural related antioxidant properties and their role on ascorbic acid preservation. Studies in Natural Products Chemistry 26:741-778.

Milagres Campos, F., S. Machado Rocha Ribero, C.M. Della Lucia, and H.M. Pinheiro-Sant'Ana. 2009. Optimization of methodology to analyze ascorbic and dehydroascorbic acid in vegetables. Quimica Nova 32:87-91.

Mrad, N.D., N. Boudhrioua, N. Kechaou, F. Courtois, and C. Bonazzi. 2012. Influence of air drying temperature on kinetics, physicochemical properties, total phenolic content and ascorbic acid of pears. Food and Bioproducts Processing 90:433-441.

Perera, C.O. 2005. Selected quality attributes of dried foods. Drying Technology 23:717-730.

Podsędek, A. 2007. Natural antioxidants and antioxidant capacity of Brassica vegetables. A review. LWT-Food Science and Technology 40:1-11.

Prathapan, A., M. Lukhman, C. Arumughan, P. Sundaresan, and K. Raghu. 2009. Effect of heat treatment on curcuminoid, colour value and total polyphenols of fresh turmeric rhizome. International Journal of Food Science and Technology 44:14381444.

Puente, L.A., C.A. Pinto-Muñoz, E.S. Castro, and M. Cortés. 2011. Physalis peruviana Linnaeus, the multiple properties of a highly functional fruit: A review. Food Research International 44:1733-
1740.

Rockenbach, I.I., E. Rodrigues, C. Cataneo, L. Gonzaga, A. Lima, J. Mancini-Filho, e R. Fett. 2008. Ácidos fenólicos e atividade antioxidante em fruto de Physalis peruviana L. Alimentos e Nutrição Araraquara 19:271-276.

Rufino, M. do S., J. Pérez-Jiménez, S. Arranz, R. Elesbão Alves, E. de Brito, M. Oliveira et al. 2011. Açaí (Euterpe oleraceae) 'BRS Pará': A tropical fruit source of antioxidant dietary fiber and high antioxidant capacity oil. Food Research International 44:21002106.

Salazar, M.R., J.W. Jones, B. Chaves, and A. Cooman. 2008. A model for the potential production and dry matter distribution of Cape gooseberry (Physalis peruviana L.) Scientia Horticulturae 115:142-148

Stojanovic, J., and J.L. Silva. 2007. Influence of osmotic concentration, continuous high frequency ultrasound and dehydration on antioxidants, colour and chemical properties of rabbiteye blueberries. Food Chemistry 101:898-906.

Turkmen, N., F. Sari, and Y.S. Velioglu. 2005. The effect of cooking methods on total phenolics and antioxidant activity of selected green vegetables. Food Chemistry 93:713-718.

Uribe, E., A. Vega-Gálvez, K. Di Scala, R. Oyanadel, J. Saavedra, and M. Miranda. 2011. Characteristics of convective drying of pepino fruit (Solanum muricatum Ait.): Application Weibull distribution. Food and Bioprocess Technology 48:1349-1356.

Vasco, C., J. Ruales, and A. Kamal-Eldin. 2008. Total phenolic compounds and antioxidant capacities of major fruits from Ecuador. Food Chemistry 111:816-823.

van het Hof, K.H, C.J. de Boer, L.V.M. Tijburg, B.R.H.M. Lucius, I. Zijp, C.E. West, et al. 2000. Carotenoid bioavailability in humans from tomatoes processed in different ways determined from the carotenoid response in the triglyceride-rich lipoprotein fraction of plasma after a single consumption and in plasma after four days of consumption. Journal of Nutrition 130:1189-1196.

Vega-Gálvez, A., K. Di Scala, K. Rodríguez, R. Lemus-Mondaca, M. Miranda, J. López, and M. Pérez-Won. 2009. Effect of air-drying temperature on physico-chemical properties, antioxidant capacity, colour and total phenolic content of red pepper (Capsicum апnиит, L. var. Hungarian). Food Chemistry 1174:647-653. 